\title{
Eleitoras: participação política e comportamento eleitoral feminino nos anos 1950 em São Paulo*
}

\author{
Female voters: political participation and female electoral behavior \\ in the 1950s in São Paulo
}

\section{Murilo Leal Pereira Neto*}

\begin{abstract}
Resumo: O texto analisa a participação política das mulheres em sindicatos, associações femininas, sociedade amigos de bairro e, destacadamente, seu comportamento como eleitoras nas eleições de 1954. São ponderados fatores como escolaridade, participação no mercado de trabalho e estatuto da mulher no código civil buscando-se compreender as possibilidades de participação feminina nos espaços formais da política e as consequências de suas ações coletivas na criação de novas formas e espaços.
\end{abstract}

Palavras-chave: eleições; política; mulheres.

\begin{abstract}
The text analyzes the electoral behavior and political participation of women in unions, women's associations, neighborhood-friendly society and, in particular, their behavior as voters in the 1954 elections. Factors such as education, participation in the labor market and the status of women in the civil code are considered, seeking to understand the possibilities of female participation in formal spaces of politics and the consequences of their collective actions in the creation of new forms and spaces.
\end{abstract}

Keywords: Elections; Politics; Women.

* Este artigo é parte dos resultados de pesquisa de pós-doutorado desenvolvida junto ao Programa de Pós-Graduação em História da Unicamp, Departamento de História, linha de pesquisa História Social do Trabalho, com tutoria do prof. Fernando Teixeira da Silva.

** Doutor em História Social pela Universidade de São Paulo (USP). Professor da Universidade Federal de São Paulo (UNIFESP), Campus Osasco. ORCID: https://orcid.org/0000-0001-8013-8007. E-mail: mlealpereira@ terra.com.br. 
possível identificar, nas eleições de 1954 em São Paulo, características específicas de um comportamento eleitoral feminino? Que peso eleitoral e que peso político a opinião feminina teve naquela conjuntura? Era diferente do ponto de vista masculino? E com relação às mulheres trabalhadoras - metalúrgicas e têxteis - é possível identificar um proceder político próprio? E as sociedades amigos de bairros, o que nos revelam sobre a participação das mulheres? Esta é a temática do presente artigo. ${ }^{1}$

Para uma aproximação mais direta ao problema da atuação eleitoral feminina, contamos apenas com dados demográficos e pesquisas de opinião do Ibope. Cruzando informações de ambas as fontes, pode-se delinear um panorama inicial para interpretação.

\section{Mulheres na legislação eleitoral e no Código Civil}

\section{É IMPORTANTE LEMBRAR que o Código Eleitoral de 1950 tornava obrigatório o alistamento apenas} para mulheres que exerciam profissões lucrativas (artigo 4을 inciso l-d). Consequentemente, a composição do eleitorado conforme os sexos era extremamente desigual. Segundo matéria publicada no Diário de S. Paulo, em 1954 havia em todo o estado 1.563 .749 eleitores e apenas 638.088 eleitoras. $^{2}$ O Censo de 1950 apurou, para o estado de São Paulo, uma população adulta de brasileiros e brasileiras natos e naturalizados, entre 20 e 69 anos, de 1.964.196 mulheres e 2.064.079 homens. ${ }^{3}$ Comparando-se os dois conjuntos de dados, conclui-se que cerca de $32,48 \%$ da população adulta feminina e aproximadamente $79 \%$ da masculina exerciam o direito ao voto.

Não sabemos quantas mulheres não obrigadas por lei se alistaram e votaram, mas podemos fazer uma aproximação. Ainda segundo o Censo de 1950, 637.062 mulheres trabalhavam de forma remunerada em São Paulo. ${ }^{4}$ Como se nota, um número bem aproximado ao de eleitoras. Trata-se, porém, de uma coincidência fortuita, pois entre as trabalhadoras remuneradas estão incluídas pessoas a partir de dez anos de idade, também

1 Agradeço a José Francisco de Oliveira Mattos pela colaboração técnica e intelectual na revisão e elaboração da versão final deste artigo.

2 "Instalado solenemente o posto central da campanha paulista pró-alistamento eleitoral". Diário de S. Paulo (Record Lux Jornal) s/d. Centro de Memória Eleitoral - TRE São Paulo - Caixa 7948 - Pasta 1 - Documentação preparatória para as eleições. Cabe observar que essa foi a única fonte em que encontramos informação sobre o percentual de homens e mulheres no eleitorado. Nas edições pesquisadas de O Estado de São Paulo, Folha de S. Paulo, Última Hora e nos censos do IBGE, nada consta. De acordo com a matéria, porém, o eleitorado total (2.201.837) é bem inferior ao indicado oficialmente pelo IBGE (2.257.309), aproximando-se do número de eleitores que realmente compareceu às urnas (1.912.764, portanto 69,99\% do total. Cf.: https://seculoxx. ibge.gov.br/images/seculoxx/arquivos_download/representacao_politica/1955/rep_polit_1955aeb_2.pdf. Apesar de todas as ressalvas e, de forma apenas aproximativa, desenvolvemos o raciocínio a seguir, na esperança do surgimento de dados mais precisos em futuras pesquisas.

3 O voto era obrigatório para maiores de 18 anos. As coortes do IBGE, porém, agrupam as idades de cinco em cinco ou dez em dez anos, conforme a faixa etária. Tivemos, portanto, de excluir eleitores e eleitoras de 18 e 19 anos. Tampouco incluímos o pequeno número acima de 70 anos, pois o voto não era obrigatório para esta faixa etária.

4 Nessa categoria estão incluídos "empregados", "empregadores", "por conta própria", "membros da família e outra posição" e "sem declaração de posição". É provável que pelo menos parte mulheres incluídas nestas rubricas exercessem atividades não remuneradas, mas como o censo reserva uma rubrica para "atividades não remuneradas" e outra para "inativos", é razoável compreender as anteriores como atividades remuneradas. 
as acima de 70 anos, além de estrangeiras e analfabetas, não sabemos em que proporção. Assim, teríamos de deduzir da população feminina que trabalhava em troca de remuneração, sendo obrigada, portanto, a alistar-se na Justiça Eleitoral, as que não estavam habilitadas por serem menores de 18 anos, estrangeiras ou analfabetas, o que resultaria em um número de cidadãs compulsoriamente alistáveis inferior ao de eleitoras, o que significa que uma parte das mulheres residentes em São Paulo que trabalhava sem remuneração alistou-se voluntariamente. E essa população, reunida pelo censo no ramo abrangente e impreciso de "atividades domésticas não remuneradas e atividades escolares discentes", incluía a esmagadora maioria da população feminina de 10 anos para cima: 2.488 .853 pessoas, quase o quádruplo, como é possível notar, das mulheres com profissões remuneradas.

A legislação eleitoral estava no compasso do Código Civil então vigente, promulgado em 1916, que impedia à mulher "litigar em juízo civil ou comercial" sem a autorização do marido (com algumas exceções, por exemplo, quando o marido estivesse "em lugar remoto, ou não sabido" - artigo 251, inciso I) e mesmo exercer profissão contra a vontade do cônjuge (artigo 242, inciso VII).

Examinando na outra ponta do processo político-eleitoral, a do corpo de representantes, tomando-se como recorte as candidatas a uma cadeira na Câmara Federal, encontramos uma presença feminina tão reduzida que é possível citar os nomes sem cansar o leitor ou a leitora e ao mesmo tempo homenagear essas ativistas. Pelo PRT, de 13 nomes lançados, duas eram mulheres: Araci Alves dos Santos e Francisca de Souza Machado; pelo PSP, de 43 postulantes, também apenas duas mulheres: Letícia Lagreca Merlo e Maria Amélia Prado da Silva Costa; o PTB, por sua vez, lançou três, entre 36 candidatos: Adoração Vilar, Ivete Vargas e Doralisa Americano Freire Tinoco; e, por fim, a UDN abriu espaço, no rol de 17 candidatos, para a veterana Carlota Pereira de Queirós, que fora a primeira deputada federal da história do Brasil, eleita para o Congresso Constituinte de 1934. Os demais partidos reservaram aos homens o monopólio absoluto das candidaturas: PDC - 21 nomes, PSB - 19, PSP/PR - 35, PTN - 23 e PST - $18 .^{5}$

A única eleita foi Ivete Vargas, com expressivos 48.282 votos. Qualquer que tenha sido a repercussão de sua campanha junto ao público feminino é óbvio que o parentesco com o presidente morto foi determinante para esse resultado, e para sua penetração no eleitorado em geral. Para a Assembleia Legislativa, não reunimos informações sobre candidatas, mas entre 75 parlamentares eleitos, apenas uma mulher: Maria da Conceição Neves Santamaria, também pelo PTB.

É evidente, portanto, que as mulheres encontravam um bloqueio a sua participação política. A barreira jurídica caíra com o Código Eleitoral de 1932 (embora, à diferença dos homens, o voto fosse então facultativo para as mulheres), mas permaneciam praticamente incólumes barreiras econômicas e culturais. As primeiras podem ser percebidas por trás dos

$\overline{5}$ Centro de Memória Eleitoral - TRE São Paulo - Caixa 7500 - Pastas 1 e 2. 
números citados anteriormente: segundo o Censo de 1950, 2.791.819 homens exerciam atividades remuneradas em São Paulo contra 315.640 classificados na rubrica das "atividades domésticas não remuneradas e atividades escolares discentes", ao passo que com as mulheres acontecia uma proporção inversa: 637.529 trabalhavam de forma remunerada contra 2.488.853 que executavam trabalhos domésticos não remunerados ou eram estudantes. É a alocação da mulher nesse trabalho, fundamental para a "produção antroponômica", 6 para a produção de valores de uso ${ }^{7}$ e a preservação da vida pelo "cuidar", ${ }^{8}$ atividades sem valor de mercado, portanto, não remuneradas e não reconhecidas pelo Estado como profissão, o fator determinante estrutural de sua condição de subalternidade.

\section{Casamento e hegemonia masculina}

O ESTATUTO DA SUBALTERNIDADE FEMININA não é estabelecido, em 1954, pelo código trabalhista ${ }^{9}$ e nem ostensivamente pelo eleitoral, mas sim pelo contrato nupcial ${ }^{10}$ e pela naturalização cultural de relações sociais hierárquicas em que uma certa identidade de gênero é aceita como "destino". Ao assinar uma certidão de casamento a mulher estava juridicamente aceitando as disposições do Código Civil segundo as quais o marido era o "chefe da sociedade conjugal" e tinha o poder, entre outras coisas, de anular o casamento se constatasse o "erro essencial" do "defloramento da mulher, ignorado pelo marido" (artigo 219 , inciso IV) ou de não autorizar, como já mencionado, o exercício de uma profissão.

O domínio masculino era exercido na forma de um tipo de hegemonia, combinação de força, inclusive física, e consentimento. Este último era obtido com inúmeros recursos, o principal era a hipervalorização do casamento e das atividades femininas na esfera doméstica, esvaziadas, porém, de sua natureza de trabalho abstrato (já que não podia ser equalizado e medido em relação a outros trabalhos pela lei do valor) e, consequentemente, concreto, já que, por não ter valor de mercado, não era valorizado ou nem sequer visto. As atividades femininas eram louvadas como manifestações de um dom e de um sentimento. A natureza sacramental do matrimônio em um país de $93,49 \%$ de católicos ${ }^{11}$ trazia o reforço da Igreja ao ordenamento

6 Danièle Combes e Monique Haicault argumentam que no seio de toda formação social encontram-se articuladas a produção (de bens) e a reprodução (produção de seres humanos). A produção de seres humanos é teorizada como produção antroponômica. Cf.: COMBES, Danièle; HAICAULT, Monique. Produção e reprodução: relações sociais de sexos e de classes. In: BULPORT-KARTCHEVSKY, Andrée et al. O sexo do trabalho. Tradução de Sueli Tomazini Cassal. Rio de Janeiro: Paz e Terra, 1986. p. 31-33.

7 Como assinala Odette Carvalho de Lima Seabra: "A produção doméstica, oriunda dos próprios quintais, embora nunca tenha sido contabilizada, foi suporte da produção de valores de uso: as frutas, as hortas e mesmo a criação de animais domésticos". Cf.: SEABRA, Odette Carvalho de Lima. Urbanização e fragmentação: cotidiano e vida de bairro na metamorfose da cidade em metrópole, a partir das transformações do Bairro do Limão. 2003. Tese (Livre-Docência em Geografia) - FFLCH, Universidade de São Paulo, São Paulo, 2003. p. 224.

8 Sobre o care como componente do trabalho reprodutivo, Cf.: BORIS, Eileen. Produção e reprodução, casa e trabalho. Tempo Social, São Paulo, v. 26, n. 1, p. 101-121, jun. 2014.

9 Toda a regulamentação do trabalho feminino na CLT pode ser classificada, pelo menos formalmente, como "discriminação positiva". Ver especialmente o capítulo 3.

10 É significativo que o Código Civil vigente em 1954 contém uma série de dispositivos subordinando a mulher ao marido, mas não as maiores de idade (acima de 21 anos) aos homens.

11 Segundo o censo de 1950 . Os protestantes somavam 3,35\% da população, os espíritas 1,59\%. Depois vinham 
jurídico para a introjeção do casamento agora já não como "sociedade conjugal", mas como laço sagrado e eterno. A mídia dominante reforçava a operação de convencimento através entre outros dispositivos - das diversas revistas dirigidas ao público feminino, como o Jornal das Moças, Claudia, Querida, Vida Doméstica, A Casa, Você, Capricho, Grande Hotel. ${ }^{12}$ Finalmente, rituais populares como as eleições das rainhas e princesas dos trabalhadores, do $1^{\circ}$ de Maio ou das festas da uva e do vinho (entre outras), ao mesmo tempo em que enalteciam o papel da mulher trabalhadora, reforçavam uma identidade de gênero associada à "beleza", "humildade", "bondade", qualidades associadas ao trabalho doméstico e à subalternidade. ${ }^{13}$ Assim, a grinalda ou a coroa ajudavam a tornar os grilhões mais leves e até desejáveis.

A pesquisa de Bassanezi no Jornal das Moças não deixa dúvida sobre o imenso trabalho de convencimento visando manter as mulheres afastadas da política e dos assuntos econômicos e satisfeitas nas atividades domésticas. Em primeiro lugar pelos assuntos oferecidos:

Grande parte das páginas da revista é dedicada a assuntos domésticos, considerados prioridades das mulheres. São inevitáveis os numerosos conselhos e artigos referentes à culinária, prendas manuais, decoração, organização do lar. Há também seções especiais sobre o cuidado com os filhos: "Evangelho das mães" - sobre a "sagrada missão da maternidade" - e "Falando às mães" - conselhos do Dr. Werther, médico especialista. ${ }^{14}$

Junto a isto, o consentimento à subalternidade era obtido com a atribuição de uma auréola às responsabilidades familiares e domésticas decorrentes do matrimônio e com a ameaça de sua perda em consequência do ingresso no mercado de trabalho e do envolvimento com a política. Ainda segundo Bassanezi: "Política e economia - a não ser a doméstica - não são de forma alguma consideradas 'assuntos de mulher'. Fazendo um balanço do ano de 1964, Claudia menciona a ascensão meteórica dos Beatles, mas nem sequer cita a dos militares com o golpe". ${ }^{15}$ Se isto era assim em 1964, também assim era dez ou vinte anos antes. Em 1944, o Jornal das Moças asseverava que "o casamento é a verdadeira estrutura da sociedade. É na família que se baseia todo o esplendor de um povo sadio". ${ }^{16} \mathrm{O}$ ingresso no mercado do trabalho é apresentado como uma verdadeira ameaça:

Artigos que tratam dos problemas e impasses na relação homem-mulher decorrentes do trabalho feminino afirmam que a mulher não deve perder sua feminilidade sob a ameaça de perder o "amor", o "respeito", a "proteção" dos homens e os privilégios de seu sexo, acabando por entrar no mundo "competitivo" e cruel que é o mundo fora do lar [grifo da autora]. ${ }^{17}$

\footnotetext{
"budistas", "israelitas". As religiões de matriz afro-brasileira nem sequer eram mencionadas.

12 Cf.: BASSANEZI, Carla. Virando as páginas, revendo as mulheres: revistas femininas relações homem-mulher (1945-1964). Rio de Janeiro: Civilização Brasileira, 1996. p. 33.

13 Segundo Mirta Lobato, as rainhas do trabalho sob o peronismo deveriam ser humildes, belas, de bom coração e boas peronistas. Cf.: LOBATO, Mirta Zaida; DAMILAKOU, María; TORNAY, Lizel. Las reinas del trabajo bajo el peronismo. In: LOBATO, Mirta Zaira (ed.). Cuando las mujeres reinaban: belleza, virtud y poder en la Argentina del siglo XX. Buenos Aires; Editorial Biblos, 2005. p. 99.

14 BASSANEZI, op. cit., p. 25.

15 Ibidem, p. 40.

16 Ibidem, p. 255.

17 Ibidem, p. 218.
} 
O resultado foi, não sem resistências, a introjeção dos valores hegemônicos. Segundo Bassanezi, o trabalho remunerado feminino imediatamente após a Segunda Guerra e nos anos 50 poderia ser até mesmo motivo de pejo para a família, ou pelo menos para os membros masculinos: "Alguns pais e maridos chegam a se envergonhar por terem filhas ou esposas trabalhando fora do lar, pois isto pode ser interpretado como incapacidade em cumprir o 'dever masculino' de provedor da casa". ${ }^{18}$

O casamento e a maternidade eram apresentados nas revistas femininas citadas, nos anos 1940 e 50, "como um destino natural traçado para todas as mulheres. Ligado a uma noção de essência feminina, este destino surge como praticamente incontestável". ${ }^{19} \mathrm{~A}$ mesma percepção é encontrada em 1986 em entrevistas realizadas por Elisabeth Souza-Lobo com três operárias da indústria de autopeças em São Paulo: "As três mulheres consideram-se capazes de sobreviver sós, mas compartilham um destino de mulheres construído pela família, os filhos para cuidar, enquanto os homens não parecem ter um destino, seus caminhos podem ser feitos e refeitos". ${ }^{20}$ Coincidentemente, ao concluir um volume de estudos sobre a coroação das rainhas do trabalho ou da colheita na Argentina, com foco principal nos anos 1940 e 50, a historiadora Mirta Lobato destaca que, sob o primeiro governo peronista, apesar das mulheres terem conquistado o direito ao voto, "parecia impossível escapar ao 'destino' de mulher", o que significava "sacrificar-se silenciosamente e estar a serviço dos outros". ${ }^{21}$ Entretanto, apesar do trabalho assalariado não parecer às próprias mulheres como abertura para um outro destino (já que o fardo do papel social não se altera necessariamente), a condição de "moça de fábrica" significava, sim, uma mudança de destino. Analisando transformações da vida cotidiana no Bairro do Limão, assinala Seabra: "Moça de fábrica chegou a ser uma designação genérica e de certa forma pejorativa [...] se tornou quase um estereótipo de uma mulher que trabalhava fora e que traçava outros percursos na vida. Mostrava-se mais livre. Conheceu outras pessoas, conheceu a cidade [...]" ${ }^{22}$

Os benefícios auferidos pela hegemonia masculina são muitos. Em meados dos anos 1950, o principal era o equacionamento da reprodução das relações capitalistas de produção nas condições históricas dadas, por um tipo de articulação entre o trabalho produtivo e o reprodutivo. Nesta estrutura, ao homem era outorgado o papel, como vimos, de "chefe da sociedade conjugal", com os privilégios que tal condição conferia, inclusive o de "ter um destino". No mercado de trabalho, a hegemonia masculina podia ser contabilizada em valores sonantes; segundo Safiotti, de 1920 a 1960, a proporção entre salários masculinos e femininos era muito parecida: na indústria têxtil, o salário médio das operárias adultas representava $70,6 \%$ do salário médio do operário adulto; nas indústrias de alimentação, 57,9\%, nas de

18 Ibidem, p. 211

19 Ibidem, p. 56

20 SOUZA-LOBO, Elisabeth. A classe operária tem dois sexos: trabalho, dominação e resistência. São Paulo: Fundação Perseu Abramo, 1991. p. 88.

21 LOBATO, Mirta Zaida. Belleza femenina y política: um epilogo posible. In: LOBATO, op. cit., p. 180.

22 SEABRA, op. cit., p. 227. 
vestuário e toucador, $54,5 \% .{ }^{23}$ No campo político, como demonstrado, verificava-se uma aberrante sub-representação feminina.

\section{Resistência feminina}

A HEGEMONIA DO PADRÃo de papéis e relações de gênero que estamos descrevendo não se construiu sem contestações e resistências, que se manifestaram de diversas formas. Mesmo no âmbito mais restrito das revistas femininas, mais para o começo da década de 1960, forças que podem ser entendidas como "emergentes", nos termos de Raymond Williams, se manifestaram com nitidez. ${ }^{24}$ Em 1961, aparece a revista Claudia com um projeto de atualização da hegemonia, como se nota no editorial enviado aos anunciantes em julho, antes do lançamento da revista, citado por Bassanezi:

Por que Claudia? O Brasil está mudando rapidamente. A explosiva evolução da classe média torna necessária uma revista para orientar, informar e apoiar o crescente número de donas de casa que querem (e devem) adaptar-se ao ritmo da vida moderna [grifo da autora]. ${ }^{25}$

A "vida moderna" batia às portas das donas de casa, que deveriam abri-las, mas permanecer lá dentro... De toda forma, é nessa revista que, a partir de setembro de 1963, ganhará espaço a coluna $A$ arte de ser mulher, de Carmen da Silva, psicanalista, jornalista e escritora que defendia o papel das mulheres como protagonistas de suas próprias vidas, enfrentando "os séculos de educação altamente restritiva e baseada em conceitos falsos [que] deixaram às mulheres um pesado lastro de inibições, receios, hábitos de dependência e rotina mental". ${ }^{26}$ Seus conselhos, no período de dois anos analisados por Bassanezi (1963-1964), admitiam a separação do casal por iniciativa da mulher, no caso de traição; ${ }^{27}$ a fruição do sexo por prazer; ${ }^{28}$ e orientavam a preparação material e psicológica para os desafios dos estudos e da profissão. ${ }^{29}$

Outro espaço, na mesma revista Claudia, pelo qual se insinua o elemento emergente é o reservado a artigos e cartas das leitoras. Em agosto de 1962, por exemplo, foi publicado texto de Nilza Vibonati defendendo o divórcio (transformado em lei apenas em 1977), que "parece soar como uma bomba ameaçadora diante das pregações mais comuns nas revistas femininas", gerando intenso debate por meio de "cartas, telegramas e telefonemas sem conta". ${ }^{30}$ De acordo com a pesquisa de Bassanezi, aliás, a proporção de mulheres desquitadas vai subindo a cada década, de 1940 a 1960, segundo dados censitários. ${ }^{31}$

23 SAFFIOTTI, Heleieth I. B. A mulher na sociedade de classes: mito e realidade. Petrópolis: Vozes, 1979, p. 136

24 Cf. WILLIAMS, Raymond, Cultura. Tradução de Lólio Lourenço de Oliveira. São Paulo: Paz e Terra, 1992. p. 201-203; CEVASCO, Maria Elisa. Para ler Raymond Williams. São Paulo: Paz e Terra, 2001. p. 149-150.

25 BASSANEZI, op. cit., p. 38.

26 Ibidem, p. 431.

27 Ibidem, p. 434.

28 Ibidem, p. 435.

29 Ibidem, p. 441.

30 Ibidem, p. 419.

31 Ibidem, p. 412. 
Com relação ao grau de instrução, nota-se também tendência à equiparação entre os sexos na alfabetização, na educação chamada "elementar" (hoje ensino fundamental) e média, aparecendo, entretanto, uma grande barreira de acesso ao ensino superior. Em 1950, 40,44\% da população com cinco anos de idade ou mais do estado de São Paulo era analfabeta, sendo 1.397.916 homens $(35,21 \%$ do total de homens) e 1.755 .482 mulheres $(45,86 \%$ do total de mulheres). Para este item abordado pelo censo, os dados são desagregados por idade, e é interessante notar que a tendência havia se invertido entre as crianças em 1950: entre a população de 5 a 9 anos, 434.699 homens e 416.815 mulheres não dominavam a leitura e a escrita. Nas demais coortes, o número de mulheres é sempre mais elevado que o de homens.

A defasagem de acesso à educação vai aumentando conforme o grau de ensino. Para a população no estado com 10 anos ou mais, 865.015 mulheres e 928.523 homens haviam completado o "grau elementar", em ambos os casos quase mesmo percentual de $(27,25 \%$ para homens e 26,36\%). Com relação ao "grau médio", 32162.904 homens (4,78\%) e 146.181 mulheres $(4,45 \%)$ concluíram o curso; quanto à finalização do curso superior a diferença crescia significativamente: 40.800 homens (1,20\%) e 4.729 mulheres (0,14\%). Em uma análise sumária, pode-se dizer que as famílias que podiam encaminhavam as crianças e jovens para o ensino médio, sem uma contrastante diferença entre os sexos. Na idade própria ao ingresso no ensino superior, por ser preparatório para o mercado de trabalho, por haver uma oferta mais reduzida de vagas na rede pública e, possivelmente, por ser mais caro na rede particular do que os níveis anteriores, os percursos educacionais de homens e mulheres se bifurcavam. Chegada a idade do casamento, as mulheres ficavam apenas com a grinalda e os homens com o canudo.

As mudanças chegarão em 1962 ao Código Civil, com a promulgação da Lei 4.121, também conhecida como "Estatuto da Mulher Casada". As mulheres casadas saem da condição de "incapazes relativamente a certos atos", onde figuravam ao lado de "silvícolas" e menores de idade. O marido deixa de ser o "chefe da sociedade conjugal" e ponto, tendo o seu poder relativizado e condicionado: "O marido é o chefe da sociedade conjugal, função que exerce com a colaboração da mulher, no interesse comum do casal e dos filhos" (artigo 233). Suas competências permanecem praticamente as mesmas, com uma importante exceção: perde "o direito de autorizar a profissão da mulher e a sua residência fora do teto conjugal". Cai por terra, também, o impedimento da mulher casada litigar em juízo civil ou comercial sem autorização do marido (artigo 242).

Quanto às vantagens salariais auferidas pelos homens com a hegemonia do padrão de relações de gênero vigente, estas teriam longa vida, tornando evidente que mesmo mudanças jurídicas, políticas e sociais não resultavam necessariamente em igualdade socioeconômica real. Ora, a crescente incorporação feminina à população economicamente ativa era uma tendência moderna, mas se resolvia pelo lado negativo: pela atratividade de uma força de

32 Na época, o ginasial mais o curso colegial. 
trabalho mais barata. ${ }^{33}$ De fato, como afirmou Safiotti, as desigualdades salariais não mudaram muito entre 1920 e 1960 e podem até ter piorado depois. Com base na Rais (Relação Anual de Informações Sociais) de 1979, Souza-Lobo apurou, por exemplo, que o salário feminino na indústria têxtil representava, em média, $49 \%$ do masculino e na metalúrgica, abrangendo seus quatro ramos, a média era de $50 \%$ dos salários masculinos. ${ }^{34}$ Proni \& Proni, por sua vez, apuraram que nos estabelecimentos industriais brasileiros em 2015, em geral, as mulheres recebiam apenas $66,1 \%$ dos salários masculinos. ${ }^{35}$

Considerando que, entre os setores de atividade mais densamente povoados pela força de trabalho feminina em 1950 no estado de São Paulo, a indústria de transformação figurava em segundo lugar (com 169.637 mulheres e 631.688 homens), com a prestação de serviços em primeiro (201.435 mulheres e 211.698 homens); considerando ainda que a indústria têxtil era das que mais empregavam mulheres $(66,8 \%$ do operariado têxtil no estado de São Paulo em 1950 era integrado por mulheres ${ }^{36}$ ), pode ser instrutivo, por sua representatividade, analisar como o problema aparecia nas assembleias e reuniões do Sindicato dos Têxteis.

\section{Participação sindical e política das trabalhadoras têxteis}

POSTO QUE O PADRÃo de relações de gênero com dominação masculina era a forma hegemônica, os sindicatos operários também o reproduziam: suas diretorias eram ocupadas majoritariamente e com frequência exclusivamente por homens, as reivindicações das mulheres não eram priorizadas e os papéis tradicionais mantinham-se. Ao mesmo tempo, não é exagerado dizer que, mais do que o parlamento, os partidos e as revistas voltadas ao público feminino (mas menos do que as organizações de mulheres), essas entidades, especialmente as representativas de categorias com forte presença feminina, como a têxtil, eram permeáveis ao elemento emergente de contra-hegemonia.

Em primeiro lugar, porque nas assembleias sindicais nos anos 1950, as mulheres faziam ouvir sua própria voz em alto e bom som, o que, aliás, apesar de sua singeleza, não deixava de ser um acontecimento na história sindical, uma vez que, durante o período do Estado Novo, as mulheres não falavam nas assembleias e pouco compareciam. ${ }^{37} \mathrm{Na}$ assembleia têxtil realizada no Cine São José, no Belém, em 21 de fevereiro de 1953 (data muito próxima

33 Em 1960, quase oito em cada dez homens aptos a trabalhar buscavam trabalho no mercado, enquanto apenas duas mulheres o faziam. Em 50 anos, a incorporação feminina à PEA quase quadruplicou. Cf.: GUIMARÃES, Nadya Araújo; BARONE, Leonardo Sangali; BRITO, Murilo Marschner Alves de. Mercado e mercantilização do trabalho no Brasil (1960-2010). In: ARRETCHE, Marta (org.). Trajetória das desigualdades: como o Brasil mudou nos últimos cinquenta anos. São Paulo: Editora Unesp; CEM, 2015. p. 406.

34 SOUZA-LOBO, op. cit., p. 31

35 PRONI, Thaissa Tamarindo da Rocha Weishaupt; PRONI, Marcelo Weishaupt. Discriminação de gênero em grandes empresas no Brasil. Revista Estudos Feministas, Florianópolis, v. 26, n. 1, p. 1-21, 2018.

36 ALMEIDA, Márcia Mendes de. O Sindicato dos Têxteis em São Paulo: História (1933-1957). 1981. Dissertação (Mestrado em Sociologia) - FFLCH, Universidade de São Paulo, São Paulo, 1981. p. 180.

37 Joel Wolfe entrevistou 35 operárias e operários têxteis e metalúrgicos e nenhum se lembrava de uma oradora nas assembleias naquele período. Cf.: WOLFE, Joel. Working women, working men: Sao Paulo and the Rise of Brazil's Industrial Working Class, 1900-1955. Durham: Duke University Press, 1993. p. 81. 
da Greve dos 300 mil, que se iniciaria em 26 de março), Maria Sallas, militante do PCB, pediu a palavra. Um agente do serviço secreto do Dops registrou posteriormente em seu relatório uma casa lotada, com cerca de 1.500 pessoas, "ocupando plateia, frisas e camarotes". A operária não se intimidou e começou dizendo que poucas mulheres compareciam às assembleias, mas que todos deveriam estar presentes: homens, mulheres e mesmo os menores de idade. Isto porque moças e menores eram preferidos pelos empregadores: "Tais pessoas são assim exploradas e não comparecem às assembleias e isso prejudica a classe trabalhadora" ${ }^{38}$ As leis não eram cumpridas e não havia fiscalização: o trabalho noturno de mulheres era ocorrência comum. Conclamava: "Peço a todos os moços que estão aqui que tragam suas noivas, outros que tragam suas filhas. É necessário sindicalizar-se e organizar-se". Os registros de eventos como este na documentação são muitos.

Além de falar, as tecelãs participavam ativamente do movimento sindical. Joel Wolfe captou muito bem como o que estamos chamando de hegemonia de um padrão masculino nas relações de gênero se estabelecia nas organizações operárias e como também sofria alterações nos anos 1950, se atualizando. As mulheres participavam mais assiduamente de "suas próprias instituições informais (as comissões de fábrica)", e se chocavam com a liderança masculina no sindicato que as tratava, na melhor das hipóteses, de forma paternalista, e na pior, de modo misógino. A greve têxtil de 1951 representou um divisor de águas nessa relação, pois seus resultados comprovaram a eficácia de uma estratégia de mobilização de baixo para cima e, desde então, os homens e mulheres "da base" conquistaram espaço nas comissões de salário, comandos de greve, campanhas salariais.

É possível flagrar um episódio desses embates na fala da tecelã Erondina Arruda na assembleia de 8 de março de 1953, realizada no mesmo Cine São José, com a presença de 812 associados e um número não contabilizado de não associados. A operária pediu a palavra para protestar "contra a não inclusão na ata da proposta por ela apresentada e aprovada no plenário", que consistia em que "a assembleia autorize a diretoria do Sindicato e a Comissão Pró-aumento de Salários a organizar comissões nas fábricas para convidar os trabalhadores a lutar pelo aumento de $60 \%$ ". O exemplo sugere que as mulheres não só começavam a falar nas assembleias como cobravam respeito a suas propostas e estavam especialmente interessadas no respaldo do sindicato à multiplicação das comissões de fábrica. ${ }^{39}$

As diretorias dos sindicatos, mesmo de uma categoria como a têxtil, continuavam sendo monopolizadas por homens, como já observado. Das quatro chapas concorrentes nas eleições de 1955, três contavam com integrantes mulheres, mas sempre em cargos secundários. Na Chapa 1, vencedora, Eulina de Oliveira era membro do Conselho Fiscal, Hilda Julles suplente do mesmo conselho e Conceição Aro, suplente da diretoria. ${ }^{40} \mathrm{~A}$ Chapa 2

38 Arquivo do Estado de São Paulo, Deops, dossiê 50-Z-315, fl. 159.

39 Ata Assembleia Geral Extraordinária do Sindicato dos Têxteis de S. Paulo, 22 fev. 1953, p. 54.

40 Ata da reunião dos eleitos nas eleições dos dias 12 e 13 de abril de 1955 para o biênio 21/9/55 a 20/9/57, p. 51-verso. 
apresentava Maria Helena Priseajniuc como suplente da diretoria e Mergília Figueiredo como suplente do Conselho Fiscal. A Chapa 3 era a única que lançava uma mulher como membro da diretoria, Sebastiana Monteiro, provavelmente como bibliotecária, além de Valentina Darin e Ignacia Garofallo como suplentes da diretoria e Assumpção de Jesus Ribeiro como suplente do Conselho Fiscal. ${ }^{41}$

Na Comissão Central de Salários, que vinha funcionando lado a lado com a diretoria desde pelo menos janeiro de 1953 e teria papel decisivo na greve que se avizinhava, dos sete integrantes, três eram mulheres: Mariana Grigaites, Maria Sallas e Erondina Arruda. ${ }^{42}$ Há registro, ainda, de uma curiosa organização compartimentada na assembleia de 11 de janeiro, com a formação de uma "comissão central" com seis homens e de uma "comissão feminina" com cinco mulheres: além de Grigaites, Sallas, Erondina, Maria Sanches Decara e Olga Merida. ${ }^{43}$ Posteriormente a assembleia de 15 de março ampliou o número de membros da comissão para 35, com a incorporação de mais quatro mulheres: Ramona Mula Pastor, Maria las, Laudiceia Tavares e Augusta Oliveira Lima. ${ }^{44}$

A participação feminina na Greve dos 300 mil, que durou de 26 de março a 23 de abril de 1953, está bem documentada, inclusive em imagens de assembleias, indiciamento de "piqueteiras" no Dops, oradoras da Comissão Central de Greve e participantes em passeatas, integrando sua "comissão de frente". ${ }^{45}$ Não é surpresa, portanto, que os dirigentes do Sindicato dos Têxteis tenham reconhecido sua bravura. Na inauguração da exposição da artista plástica Virginia Artigas, em abril de 1956, com gravuras sobre a greve de 1953, Nelson Rusticci, presidente do sindicato, observando as obras, ressaltou a importância "dos elementos femininos que tomaram parte ativa na mencionada greve, e apontou uma senhora que também estava presente e que fora baleada na época da greve na rua da Mooca". ${ }^{46}$ Outro dirigente têxtil, Antonio Chamorro, na assembleia de 17 de maio de 1953, apresentou um relatório da greve em nome da Comissão Central de Salários, "dizendo que um dos principais fatores da vitória foi, sem dúvida, a comissão de piquetes que recebeu do plenário uma prolongada salva de palmas [...] e ressalta o importante papel desempenhado pela ala feminina que demonstrou estar perfeitamente à altura para lutar em defesa de seus direitos" . ${ }^{47}$

Pode-se concluir que, em meados dos anos 1950, a participação feminina apresentava-se, no mundo do trabalho, na cultura e na política como um elemento emergente, pressionando a ascendência masculina. Prosseguindo com a analogia já esboçada com

41 Arquivo do Estado de São Paulo, Deops, dossiê 50-Z-315, fl. 455.

42 Ata da reunião da Comissão Central Pró-aumento de Salários em conjunto com a diretoria do Sindicato dos Têxteis, 15 jan. 1953, p. 50.

43 Arquivo do Estado de São Paulo, Deops, dossiê 50-Z-315, fl. 149.

44 Ata Assembleia Geral do Sindicato dos Têxteis de São Paulo, 15 mar. 1953, p. 59.

45 Cf.: MOISÉS, José Álvaro. Greve de massa e crise política: estudo da Greve dos 300 Mil em São Paulo (1953-1954). São Paulo: Polis, 1978. p. 116 e 120; LEAL, Murilo. A reinvenção da classe trabalhadora (1953-1964). Campinas: Editora da Unicamp, 2009. p. 243 e 245.

46 Arquivo do Estado de São Paulo, Deops, dossiê 50-Z-315, fl. 664. Para ver uma das gravuras, Cf.: MULHERES. In: ENCICLOPÉDIA Itaú Cultural de Arte e Cultura Brasileiras. São Paulo: Itaú Cultural, 2020. Disponível em: http://enciclopedia.itaucultural.org.br/obra58068/mulheres. Acesso em: 16 abr. 2020.

47 Ata Assembleia Geral do Sindicato dos Têxteis de São Paulo, 17 maio 1953, p. 68. 
o pensamento de Williams referente à dominação cultural e social, pode-se dizer que a inovação da participação feminina tendia a provocar nas relações de poder dois tipos de efeitos: de ajustamento ou de destruição de algumas de suas formas. ${ }^{48}$ No primeiro caso, criavam-se espaços para o "feminino", no segundo, abria-se caminho para o "feminismo", como tentaremos demonstrar.

Uma das formas de incorporação da participação das mulheres sem transformação da dominação masculina foi tentada no movimento sindical com a criação dos departamentos femininos. No Sindicato dos Têxteis foi criado esse departamento, em fevereiro de 1958, sob a presidência da muito ativa operária da Tecelagem Mariângela, das Indústrias Reunidas Matarazzo e militante do PCB, Eulina de Oliveira. Contava, além da presidente, com uma vice, primeira e segunda secretárias, primeira e segunda tesoureiras e duas suplentes. É óbvio que as mulheres haviam conseguido, na falta de espaço na diretoria do sindicato, criar uma estrutura de poder própria. Os assuntos afetos aos departamentos femininos, porém, muito se assemelhavam aos temas tidos como "de mulher", pelas revistas femininas. A mesma edição do jornal do Sindicato dos Têxteis em que foi anunciada a criação do Departamento Feminino trazia outra matéria apresentando uma denúncia de sua presidente: a categoria era composta por $80 \%$ de mulheres que não usufruíam de "nenhuma distração nem divertimento". Era listada, em seguida, uma série de alternativas de passeios, que iam do Masp até o Horto Florestal. ${ }^{49}$ Outra matéria referente às atividades do Departamento Feminino aparece na edição de agosto de 1958 do mesmo jornal. A categoria é convidada para um piquenique em Itapevi "com muitas brincadeiras de campo, demonstrações de judô da academia feminina e masculina, grandes partidas futebolísticas, concurso e baile". A tesoureira Hilda Faura de Oliveira ressaltava: "Não vai ser um simples piquenique, mas um acontecimento social de vulto para a família têxtil. Reuniremos mais de dez mil pessoas, num grande parque, num maravilhoso local". 50

A bem da verdade, em 1958 estava sendo recriado o Departamento Feminino, pois, segundo Almeida: "No período 1939-1941 foi criado um Departamento Feminino, dirigido por Sebastiana Monteiro, que jamais abriu a boca em reuniões da diretoria ou assembleias. A diretoria eleita em 1941 aboliu aquele departamento". ${ }^{51}$

No Sindicato dos Metalúrgicos, o Departamento Feminino fora criado em 27 de dezembro de 1955. Sua diretora Antonia M. Silva, em artigo intitulado "Salve 27 de dezembro!", esclarece os objetivos da entidade:

Irá trabalhar para que, cada vez mais, as mulheres trabalhadoras se organizem, formando um elo inquebrantável dentro do nosso grandioso sindicato, onde lutarão unidas para a conquista de suas reivindicações.

48 WILLIAMS, op. cit., p. 202.

49 DEPARTAMENTO FEMININO. O Trabalhador Têxtil, n. 17, São Paulo, fev. 1958.

50 EM ITAPEVY, em grande piquenique esqueceremos as agruras da fábrica. 0 Trabalhador Têxtil, n. 21, São Paulo, ago. 1958

51 ALMEIDA, op. cit., p. 70. Sobre o mesmo assunto, cf.: WOLFE, op. cit., p. 80. 
Pretende o Departamento Feminino, além do corte e costura, organizar também outros cursos, como sejam florista, decoração de bolos, bordados, noções de enfermagem e puericultura e também a conquista da aplicação das leis que constam na legislação trabalhista, protegendo a mulher que é mãe e trabalhadora, que vive com sacrifícios enormes, sem ter onde deixar seus filhos, exploradas em seu trabalho. ${ }^{52}$

Na mesma edição do jornal, texto de Diogo Munhoz Bueno destaca outros objetivos do departamento recém-criado. Denuncia que mulheres e menores de idade estavam sendo usados mais amiúde no ramo metalúrgico sem receber o salário mínimo de 2.300 cruzeiros, apesar de fazer o mesmo trabalho. Aponta, ainda, que $90 \%$ das empresas descumpriam o artigo 389 da CLT, que determinava a instalação de creches em indústrias com mais de 30 empregadas. ${ }^{53}$

A partir da análise dessa documentação, algumas conclusões podem ser cogitadas. A criação dos departamentos femininos foi uma resposta a transformações nos papéis sociais femininos. A gradual ampliação da presença das mulheres no mercado de trabalho e na esfera pública se fazia sentir e poderia ser mobilizada como "ativo" político ou econômico por candidatos a cargos legislativos, partidos, sindicatos, mídia, ou por empresas interessadas em vender seus produtos. ${ }^{54}$ No campo sindical, não é coincidência o fato de que os departamentos femininos nos dois sindicatos estudados tenham sido criados (ou recriados, no caso dos têxteis) depois de uma profunda renovação de suas diretorias em 1952 e 1953. Mesmo sendo válidas essas considerações para o período do após a Segunda Guerra, não devem nos induzir a pensar em um processo linear de gradativa ampliação da presença feminina no mercado de trabalho, concomitante a uma crescente participação política, uma vez que no começo do século XX, em algumas áreas, como na indústria têxtil, a participação feminina na força de trabalho era ainda maior relativamente e seu ativismo sindical e político igualmente intenso, embora não em sindicatos, que estavam começando a se formar e seriam monopolizados por homens. É o que se depreende, por exemplo, da pesquisa de Faccaro sobre as ligas operárias:

Depois dos festivais do Dia do Trabalho de 1917, formou-se a Liga Operária do Belenzinho, dirigida por Maria Antônia Soares, irmã de Florentino de Carvalho, escritor e anarquista. Logo em seguida, a liga se transformou na comissão organizadora de uma federação paulista, a União Geral dos Trabalhadores, que se filiaria à Confederação Brasileira Operária [...]. Não raro, as ligas de bairro congregariam pessoas de uma mesma fábrica, como a Liga Operária da Mooca, fundada logo em seguida, cujos membros, em sua maior parte, eram mulheres empregadas no Cotonifício Crespi. ${ }^{55}$

52 SILVA, Antonia M. Salve 27 de dezembro! O Metalúrgico, São Paulo, n. 148, p. 3, jan. 1956.

53 BUENO, Diogo Munhoz. Muitas coisas esquecidas mas que agora são lembradas. O Metalúrgico, n. 148, São Paulo, p. 7, jan. 1956. O texto não especifica que a creche é obrigatória apenas no período de amamentação.

54 Bassanezi observa que, nos anos 1950, a revista Jornal das Moças estava repleta de propagandas com mensagens ousadas, se comparadas com o conteúdo dos artigos: mulheres trajando o sutiã Morisco, que "destaca toda a beleza e sedução do seu busto"; casal se beijando na boca (propaganda do batom Van Ess); moça fumando entre homens (cigarro Continental); jovens de biquini (creme dental Colgate). Cf.: op. cit., p. 29.

55 FRACCARO, Glaucia Cristina Candian. Mulheres, sindicato e organização política na greve de 1917 em São Paulo. Revista Brasileira de História, São Paulo, v. 37, n. 76, set./dez. 2017. 
A ascensão das mulheres trazia implicações nos jogos de poder na esfera pública e doméstica, no mercado do trabalho, no mundo jurídico, levantando o problema da igualdade e da diversidade. Os departamentos femininos, assim como os concursos das rainhas, parecem ter sido um espaço negociado entre homens e mulheres para ao mesmo tempo ceder poder, incorporando as mulheres e fortalecendo a entidade, mas mantendo-as prioritariamente dedicadas a "assuntos de mulher", portanto sem ameaçar diretamente o poder masculino. As várias facetas desse acordo podem ser percebidas pela análise de dois registros.

A tecelã Ignez Augusta, membro do PCB e sindicalista têxtil nos anos 1950, esclareceu sobre sua relação com a entidade:

Eu participei de várias festas do sindicato, inclusive tinha "corte e costura", nós tínhamos o advogado dr. Rio Branco Paranhos. "Corte e costura" trazia muito o pessoal para o sindicato, entende? Porque o pessoal temia esse negócio de sindicato, você convidava eles para o sindicato e eles: "Ah, eu lá vou em sindicato, negócio clandestino, negócio que leva preso" e era mesmo, não é? Muita perseguição... ${ }^{56}$

Portanto, atrair mulheres para realizar atividades como o curso de corte e costura equivalia a um movimento tático em uma luta política multifacetada: para o público feminino interessado em adquirir aquele aprendizado, bem como para suas famílias, ir ao sindicato com essa finalidade se afigurava como aceitável; o que já não aconteceria se fossem chamadas a participar de uma assembleia, por exemplo. Para as diretoras engajadas em uma militância política, como Eulina de Oliveira e Ignez Augusta, apresentava-se uma oportunidade para conversar e convencer um público mais amplo. Para os diretores do sindicato, as entidades se fortaleciam material e simbolicamente e, consequentemente, reforçavam o seu próprio poder, sem serem obrigados a uma transformação radical. O discurso de uma mulher sindicalista voltado à "família têxtil", como vimos no convite para o piquenique em Itapevi, adquiria uma ressonância que nenhum homem poderia obter.

Um segundo exemplo é o recorrente uso dos concursos de rainha em contextos de mobilização e enfrentamentos de classe na cena pública que eram o contrário da reiteração do papel decorativo feminino que o próprio concurso parecia conter. Em estudo sobre a Greve dos 300 mil, Irlys A. F. Barreira relata que a Delegacia Regional do Trabalho (DRT), em represália ao movimento, congelara nos bancos os depósitos em dinheiro dos sindicatos, por isso "as comissões de greve tentavam conseguir fundos para auxílio aos paredistas por meio de emissão de bônus e um concurso à ‘Rainha da Greve' com votos a um cruzeiro cada". ${ }^{57}$

56 Entrevista Ignez Augusta a Murilo Leal, 8 mar. 2003, p. 6. Doada ao Centro de Memória Sindical

57 BARREIRA, Irlys Alencar Firmo. Autonomia da classe operária? A greve de 1953 em São Paulo. 1977. Dissertação (Mestrado em Ciências Sociais) - ICH, Departamento de Ciências Sociais, Universidade de Brasília, Brasília, 1977. p. 87. 


\section{Federação das Mulheres, associações femininas e sociedades amigos de bairro}

Outra manifestação da emergência inovadora da pressão feminina adquiria conotações diferentes, que chamaremos de "feministas", e era representada por entidades de mulheres, como as federações e associações.

Embora não fossem feministas por seus objetivos e pautas, tampouco se assemelhavam aos departamentos femininos, organizações subordinadas a diretorias masculinas em entidades maiores. Eram associações dirigidas por mulheres, mais abertas à priorização e mobilização por pautas que interessavam às mulheres. Como se originavam, em muitos casos, de iniciativa da militância comunista, nesses espaços a agenda feminina tinha de ser negociada com bandeiras gerais, ditadas pelo PCB e, indiretamente, pelo estado soviético, como a defesa da paz no mundo ou da nacionalização do petróleo. ${ }^{58}$ Mesmo condicionado, pode-se dizer que nessas organizações o "elemento emergente" feminino tomava corpo com força transformadora.

Pode-se percebê-lo, por exemplo, no teor de algumas teses apresentadas na $1^{\text {a }}$ Convenção Feminina Estadual da Federação das Mulheres do Estado de São Paulo, realizada em março de 1949 no Salão das Classes Laboriosas. Além de textos sobre a paz e a carestia, foram apresentados outros atacando os problemas da mulher operária, como baixos salários, alimentação precária, falta de creches, refeitórios, vestiário, moradia digna e transporte.59 Sofia Campos Teixeira apresentou proposição Sobre as domésticas, defendendo para estas trabalhadoras o direito à sindicalização, à estabilidade, aposentadoria, entre outros. ${ }^{60}$ Luiza Monteiro, representante de Pinheiros, apresentou texto intitulado Igual salário para igual trabalho e a operária da Indústria Têxtil Votorantim, de Sorocaba, Salvadora Lopes, militante do PCB, apresentou tese sobre A exploração da mulher dentro da empresa e a falta de proteção à infância. ${ }^{61}$ Não faltaram teses da delegação de Taubaté, uma sobre as trabalhadoras do campo e das fábricas, não assinada, e outra de Vera Trevisan, intitulada Reivindicações de um bairro operário. ${ }^{62}$

58 Como observa Marcela Cristina de Oliveira Morente, o tema da paz era recorrente nos congressos e convenções, "de acordo com orientação da URSS" no contexto da Guerra Fria. O estatuto da Federação das Mulheres do Estado de São Paulo, fundada em 15 de abril de 1948, elencava como sua "finalidade precípua", lado a lado, "defender a paz no mundo e lutar pela conquista dos direitos da mulher". Cf.: MORENTE, Marcela Cristina de Oliveira. Invadindo o mundo público: movimentos de mulheres (1945-1964). 2015. Dissertação (Mestrado em História) - FFLCH, Universidade de São Paulo, São Paulo, 2015. p. 59.

59 Ibidem, p. 60.

60 Sofia Campos Teixeira era negra, professora, ativista social, candidata a deputada estadual em 1957 e a federal em 1950 e colaboradora de revistas e periódicos da imprensa negra brasileira, como Mundo Novo, Alvorada, O Novo Horizonte, Senzala. Cf.: OLIVEIRA, Marylu Alves de et al. Sofia Campos Teixeira e a atuação política da mulher negra no jornalismo brasileiro. Compolítica 8. Brasília: Fac-UnB, 17 a 17 maio 2019. Disponível em: http://ctpol.unb.br/compolitica2019/GT5/gt5_Oliveira_et_al.pdf. Acesso em: 18 maio 2020.

61 Ibidem, p. 62. Sobre Salvadora, Cf.: Carlos Carvalho Cavalheiro. Salvadora! Sorocaba: Crearte, 2001.

62 MORENTE, op. cit., p. 62. 
As operárias têxteis mantinham ligação com as federações de mulheres no período estudado, como é o caso de Salvadora Lopes, de Sorocaba, citada acima. No Sindicato de São Paulo, na assembleia de 18 de julho de 1954, por exemplo, foi eleita uma comissão para participar da Convenção da Federação Latino-americana de Mulheres, integrada por Eulina de Oliveira, Virgínia Vigorato, Conceição Aro, Marlene Garcia, Laurinda Novais, Rosária Amado, Hilda Amado e Maria Souto. Convém observar que Eulina de Oliveira era uma liderança ligada ao PCB e, como vimos, viria a presidir o Departamento Feminino anos depois; Rosária Amado fora lançada candidata a deputada estadual pelo Movimento da Panela Vazia naquele mesmo ano, tendo seu nome indeferido pelo TRE sob acusação de comunismo; e Marlene Garcia fora eleita, havia pouco tempo, Rainha dos Trabalhadores Têxteis, indicando o quanto este título poderia se desvincular de sua simbologia original e associar-se a outras causas. ${ }^{63}$

Poucos dias após a morte de Vargas, na assembleia têxtil de 29 de agosto, era a vez de uma representante da Federação das Mulheres do Estado de São Paulo falar em solidariedade à paralisação de 24 horas por aumento de salários e congelamento de preços, aprovada para 2 de setembro. ${ }^{64}$

Um relatório do Dops faz menção a algumas associações de bairro ligadas à Federação das Mulheres: Associação Feminina Cruzeiro (Vila Formosa), Associação Feminina Joana D’Arc (Brás), Associação Feminina Princesa Isabel (Mooca), Associação Feminina Vila Granada, assim como da Penha, Bom Retiro, entre outras. ${ }^{65}$ Essas associações reivindicavam o combate à alta do custo de vida com compras de gêneros alimentícios direto do produtor; mais escolas, postos de puericultura, jardins de infância; melhoria da assistência à maternidade e à infância; efetiva aplicação da CLT com salário igual para trabalho igual, assistência social nos locais de trabalho, entre outras. Mas também, como os departamentos femininos dos sindicatos, promoviam piqueniques com jogos de futebol, shows de artistas, baile de salão e eleição da rainha da festa, como fez a Associação Feminina de Vila Granada em fevereiro de $1956,{ }^{66}$ ou então realizavam festas dedicadas aos filhos dos moradores, com "projeção de filme para a gurizada do bairro da Mooca" e farta distribuição de doces e balas, como fez a Associação Feminina Princesa Isabel em abril daquele mesmo ano. Mas, junto com a festa e as brincadeiras, eram convidados mães e pais para discutir os problemas do bairro e a melhor maneira de resolvê-los, e outros assuntos como a carestia de vida e a anistia ampla para todos os presos políticos. ${ }^{67}$

As associações femininas no Brasil, dos anos 1940 e 50, reuniram mulheres que não conseguiam participar das tomadas de decisão nas entidades responsáveis pelas reivindicações

63 Ata da Assembleia Geral Extraordinária do Sindicato dos Têxteis, 18 jul. 1954, p.102-verso-103.

64 Ibidem, p. $105 \mathrm{v}$.

65 Arquivo do Estado de São Paulo, Deops, dossiê 50-J-104, fl. 739

66 Arquivo do Estado de São Paulo, Deops, dossiê 50-J-104, fl. 702 [Recorte do jornal Notícias de Hoje, 12 fev. 1956].

67 Arquivo do Estado de São Paulo, Deops, dossiê 50-J-104, fl. 701 [Recorte do jornal Notícias de Hoje, 22 abr. 1956]. 
nos bairros: as sociedades amigos de bairro. Os exemplos da Sociedade Amigos de Vila Matilde (SAVM) e Sociedade Amigos de Vila Brasilina (SAVB), bairros respectivamente da Zona Leste e Sudeste de São Paulo, ajudam a perceber a situação.

Entre os fundadores da SAVM, nenhuma mulher. Tampouco em qualquer das doze diretorias das quais pudemos conhecer a composição; da primeira, em 1950, até a de 197274. A quebra da prevalência masculina mereceu destaque no jornal $M B-A$ Voz Forte da Zona Leste, em 2012, quando foi eleita presidente, por unanimidade, Lúcia de Fátima Borges: "Trata-se de um fato inédito e histórico, porque a SAVM sempre foi uma entidade comandada por homens, onde as mulheres raramente participavam da diretoria". A matéria informa, ainda, que a presidente eleita tivera "forte e destacada atuação" no Conselho Popular de Saúde e no Conselho de Segurança de Vila Matilde. ${ }^{68}$

Ao ser indagado sobre a participação feminina na SAVM, o sr. Irineu Mosconi, que começou a participar da diretoria como conselheiro em 1960, filho de um dos pioneiros da entidade, o sr. Oscar Mosconi (conselheiro na primeira diretoria, de 1950, e homenageado com o nome em uma rua), esclareceu:

Não tinha, muito embora a gente sempre fazia um esforço querendo fazer uma comissão de senhoras, mas nunca foi pra frente. Porque também, naquela época, vamos dizer, nos velhos tempos mesmo, a mulher era a dona do lar e o homem é que ia fazer as atividades sociais etc., mas a mulher era mais a dona do lar mesmo. Muito embora as esposas de todos eram todas associadas; ele era associado e a esposa também; no caso, o meu pai era associado e a minha mãe era sócia, meus tios eram todos associados, diretores, mas as esposas eram sócias, os filhos eram sócios também. ${ }^{69}$

A SAVB, fundada em 1954, abriu-se mais à participação feminina. Na diretoria de 1972, a primeira e a segunda secretarias foram ocupadas por mulheres, respectivamente Nair Tubake da Costa e Ana Aparecida Pereira. A atuação de Nair Tubake deve ter se destacado e conquistado a confiança dos associados, pois em seguida elegeu-se presidente e foi reeleita até 1977, abrindo caminho para uma sucessora, Araildes Porto Ferreira Tavares. Uma matéria jornalística de 1978, assinada por uma mulher, Daise Gabriel, sublinhou essa característica da associação:

Talvez por ter uma líder do sexo feminino, os 400 sócios da Sociedade da Vila Brasilina contam com a efetiva participação de mulheres. Bastante ativas, conforme a presidente Araildes, elas têm lutado pelas melhorias diversas, especialmente uma delas que irá solucionar um grande impasse criado com a participação da mulher na produção: as creches. ${ }^{70}$

68 LÚCIA BORGES é a primeira mulher eleita presidente da Sociedade Amigos da Vila Matilde em 61 anos. Jornal MB - A Voz Forte da Zona Leste, São Paulo [Acervo sr. Orlando D’Agostinho - Cartolina 59].

69 Entrevista Irineu Mosconi a Murilo Leal, jul. 2018, p. 12.

70 GABRIEL, Daise. [Recorte de jornal de 1978, sem informação de título, fonte e data] Acervo Sociedade Amigos de Vila Brasilina (SAVB). 
A autora do texto também registra que raras sociedades amigos de bairro eram dirigidas por mulheres, lembrando-se apenas de mais três casos: na Vila Diva, Santo Amaro e Jardim Maria Estela.

A carreira de uma vereadora, Matilde de Carvalho, eleita pelo PSP em 3 de outubro de 1955, mas vinculada ao PCB, talvez seja exemplar de trajetórias políticas femininas "do lar à rua", implicando, ao mesmo tempo, uma politização da vida cotidiana e uma pressão para o reordenamento da agenda pública no sentido de sua "feminização". O diário Notícias de Hoje, do PCB, em seu suplemento feminino de 2 de setembro de 1956, traz matéria sobre a vereadora. Ilustrada por três fotografias, uma com Matilde à máquina de costura em casa, outra na cozinha coando café e uma terceira em reunião com mulheres e crianças; o texto informa que ela fora eleita "por grande número de votos femininos". Era natural de Piraju, interior de São Paulo, filha de um "velho ferroviário agente de estação" e órfã de mãe. Mudara-se para capital em 1930, trabalhando como costureira e estudara em curso mantido pela Sociedade Teosófica "[...] até que um dia fui tirar meu título de eleitor no comitê do bairro e convidaram-me para aparecer mais vezes". A primeira luta na qual se engajara foi pela construção do prédio do então Grupo Escolar Miss Browne na rua Padre Chico. Em uma festa do Dia das Mães, teria lançado a ideia de fundar uma associação feminina, que passara a funcionar na casa de uma das associadas. Entusiasmada com o projeto, desenvolvera campanha pela fundação de associações e comissões femininas em São Miguel Paulista, Vila Nova Cachoeirinha, Vila Ede, Parada Inglesa, Tucuruvi, Vila Anastácio, Lapa, Vila Brasilândia. Em seu depoimento à reportagem, Matilde ressalta: "O problema das operárias não era esquecido. Através das associações era-lhes explicada a necessidade de ingressarem em seus sindicatos", sugerindo uma circulação de mulheres operárias, e não somente donas de casa, entre as associações femininas e os sindicatos, com a associação atuando como um encorajamento e uma preparação para uma possível atuação no sindicato, entidade monopolizada por homens. Sobre sua candidatura, é ressaltada, mais uma vez, a presença feminina: "Vieram as eleições e as mulheres dos bairros sentiram a necessidade de uma representante na Câmara. Numa assembleia de vários lugares, meu nome foi proposto e aceito por unanimidade". Em 30 de janeiro de 1956, no primeiro mês de seu mandato, Matilde discursou no plenário da Câmara protestando contra o aumento de 3 cruzeiros no quilo do pão. ${ }^{71}$

\section{Opiniões políticas femininas segundo o lbope}

TUDO O QUE FOI APRESENTADO até aqui teve como objetivo traçar um quadro de referências para a análise do comportamento eleitoral feminino registrado na única fonte de nosso conhecimento que captou esta informação: as pesquisas de opinião do lbope. Apesar de

71 Arquivo do Estado de São Paulo, Deops, dossiê 50-J-104, fl.725 [Recorte do jornal Notícias de Hoje, São Paulo, 2 set. 1956]. Sobre o discurso contra o aumento do pão: Correio Paulistano, São Paulo, p. 5, 31 maio 1956. 
relevantes, porém, os dados permitem apenas inferências e deduções e não afirmações conclusivas por três motivos principais, a nosso ver. O primeiro é que não podem ser cotejados com dados oficiais do TRE sobre a distribuição da votação conforme o sexo dos eleitores, que não existem. Portanto, o que se oferece não são os dados sobre o comportamento que as eleitoras realmente tiveram no dia 3 de outubro de 1954, mas da intenção de votos da parcela entrevistada pelo lbope. O segundo, é que o protocolo da pesquisa não foi divulgado, dandose a conhecer tão somente o período de sua realização, o local (sempre São Paulo ou Rio de Janeiro) e a quantidade de pessoas entrevistadas. Não sabemos, por exemplo, se as mulheres participantes eram eleitoras "compulsórias", ou seja, se "exerciam profissões lucrativas" (conforme o Código Eleitoral) ou se não estavam entre as alistadas obrigatoriamente. Assim, podem ter influenciado nas enquetes mulheres que depois não exerceram o direito ao voto. Isto, porém, não invalida dados referentes a vários outros assuntos, além das eleições de 1954. Finalmente, cabe considerar que os dados divulgados, apesar de registrarem sempre a opinião feminina, não resultam de pesquisa realizada com o objetivo de captar o comportamento político e eleitoral das mulheres em toda a sua amplitude e complexidade. Questionários com perguntas como: "O(A) senhor(a) acredita que o mundo está caminhando para o socialismo ou, ao contrário, acha que a democracia liberal foi o ponto final e não será ultrapassada?", feitas para um público de mil pessoas no Rio e em São Paulo, em julho de 1952, selecionadas conforme sexo e renda, e publicadas no Boletim das Classes Dirigentes, interessavam bem mais às próprias "classes dirigentes", assombradas pelo espectro da Guerra Fria, do que à maioria das mulheres.

Em termos aproximativos, pode-se dizer que as opiniões políticas das mulheres divergiam das masculinas em muitos assuntos. As intenções de voto em Prestes Maia, por exemplo, evoluíram de forma muito diferente conforme os sexos. De março de 1953 a julho de 1954, a linha de apoio ao candidato udenista seguiu ascendente junto ao público feminino, caindo moderadamente de julho a agosto e voltando a subir em setembro, quando a intenção de voto desse grupo chegou a $31,7 \%$, bem acima da votação recebida pelo candidato nas urnas, $26,27 \%$. Quanto aos homens, os números mostram evolução quase sempre diferente: queda de março de 1953 a fevereiro de 1954, subida de fevereiro a julho, queda desprezível de julho a agosto e declínio novamente em setembro, terminando a série com 19,7\%, bem abaixo da votação recebida pelo candidato em 3 de outubro.

O que é possível inferir desses números? Considerando que Prestes Maia era o candidato oficial, apoiado pelo governador Lucas Nogueira Garcez e contando, se não com o apoio, pelo menos com sinais de simpatia do presidente Vargas, estariam certos os analistas do Ibope ao concluírem, sobre outra enquete de fevereiro de 1954, a respeito dos governos Dutra e Vargas, que "[...] é interessante observar que as mulheres quase sempre em matéria de julgamento de administração se mostram mais condescendentes que os homens?" $\mathrm{Na}$ referida pesquisa, à pergunta "Como classifica o atual governo do sr. Getúlio Vargas?", 40\% 
dos homens e $33 \%$ das mulheres optaram pela resposta "mau governo"; $32 \%$ dos homens e $37 \%$ das mulheres assinalaram "governo regular" e $21 \%$ dos homens e $26 \%$ das mulheres consideraram o governo "bom", autorizando o comentário dos analistas do Ibope.

Mas o próprio comentário pode ter sido influenciado por suposições sobre como deve ser o comportamento feminino, pois a mesma suposta condescendência não é uma constante. Pesquisa realizada entre julho e agosto de 1952, sobre a administração do prefeito de São Paulo Armando Arruda Pereira captou uma maior condescendência masculina, como se pode ver abaixo: ${ }^{72}$

\begin{tabular}{|l|c|c|c|}
\hline & Homens (\%) & Mulheres (\%) & Total (\%) \\
\hline Satisfeitos & 49,6 & 31,8 & 40,7 \\
\hline Indiferentes & 22 & 30,2 & 26,1 \\
\hline Descontentes & 7 & 4,4 & 5,7 \\
\hline Não opinaram & 21,4 & 33,6 & 27,5 \\
\hline
\end{tabular}

Observa-se, também, uma tendência bem maior das mulheres a se mostrarem "indiferentes" ou "não opinarem", assunto a que voltaremos posteriormente.

Que outros fatores podem ter influenciado a opinião feminina mais favorável a Prestes Maia e a masculina, contrária? Não temos resposta, mas os dados indicam que, de agosto para setembro, portanto depois do suicídio de Vargas, a intenção de voto masculina em Prestes Maia caiu de 25\% para 19,7\% e em Jânio Quadros subiu de 27,1\% para 37,9\%, ao passo que a intenção de voto feminina em Prestes Maia subiu de 26,6\% para 31,7\% e em Jânio Quadros também subiu de $22,8 \%$ para $25,5 \%$. Pode-se cogitar que a intenção de voto feminina tenha sido menos afetada pelo desfecho trágico de 24 de agosto.

Resultados finais das Eleições 1954

\begin{tabular}{|l|l|c|c|}
\hline & Partido/Coligação & Total de votos & Percentual (\%) \\
\hline Jânio Quadros & PTN/PSB & 660.264 & 35,22 \\
\hline Indiferentes & PSP & 641.960 & 34,25 \\
\hline Descontentes & UDN/PSD/PR/PDC/PST/PRC & 492.518 & 26,27 \\
\hline Wladmir de Toledo de Piza & PTB & 79.783 & 4,26 \\
\hline
\end{tabular}

O que as enquetes autorizam afirmar é que Prestes Maia era o candidato preferido pelas mulheres (31,7\% de intenção de voto em setembro, contra 27,3\% para Adhemar e 25,5\% de Jânio Quadros), com uma distribuição, entretanto, mais equilibrada do que entre os homens, que preferiram Jânio Quadros (37,9\%), seguido de Adhemar (30,6\%) e Prestes Maia $(19,7 \%)$.

Algo que se impõe claramente da série de pesquisas realizadas é a indiferença ou desinteresse das mulheres por determinados assuntos, como política partidária. Em abril de

72 IBOPE. Boletim das Classes Dirigentes, n. 89, p. 78, 27 jul. a 2 ago. 1952 [Arquivo Edgard Leuenroth]. 
1953, 53,3\% das mulheres afirmaram não saber qual era o partido de sua simpatia, contra $43,3 \%$ de homens; ${ }^{73}$ e em novembro de 1954 , à pergunta "Dos grandes partidos nacionais, PSD, UDN, PTB e PSP, a seu ver qual foi o mais prestigiado nas últimas eleições?", $77 \%$ das mulheres responderam não saber ou "nenhum" e $51 \%$ dos homens deram as mesmas respostas, uma diferença percentual significativa de $26 \%{ }^{74}$

Assuntos políticos muito específicos, requerendo um conhecimento, pode-se dizer, especializado, tampouco interessavam às mulheres. Em setembro de 1954, o lbope perguntou: "Na sua opinião, a escolha dos nomes do novo ministério, Café Filho foi uma escolha acertada ou, pelo contrário, o(a) sr(a) não está de acordo com esses nomes?", 65\% das mulheres tiveram a franqueza de não opinar, enquanto os homens foram mais ousados e apenas $43 \%$ se abstiveram. ${ }^{75}$

Temas concernentes à política econômica do governo central também recebiam atenção bem desigual conforme os sexos. Pesquisa realizada pela Confederação Nacional do Comércio (CNC) em novembro de 1954 perguntou para homens e mulheres de São Paulo: "Qual dessas medidas, no seu entender, deveria ser tratada em primeiro lugar pelo nosso governo: aparelhar os portos; construir estradas para o escoamento da produção; transferir a capital do país para o interior; exportar mais produtos; explorar o petróleo para deixar de importá-lo?". Dos homens, apenas $10 \%$ não opinaram, e das mulheres, $26 \%$. $^{76}$

Com relação às eleições para governador em 1954, pode-se inferir que o interesse feminino era muito menos intenso no começo do ano, e foi crescendo até equiparar-se ao masculino, praticamente na margem de erro, às vésperas do pleito. Em fevereiro de 1954, $11,8 \%$ dos homens não tinham nenhum candidato a governador, ou não opinaram, contra $26,4 \%$ das mulheres, uma diferença, portanto, de $14,6 \%$ pontos percentuais. Em setembro, a distância caíra para $4 \%$, o que se explica pelo fato de que, entre os homens, o desinteresse por qualquer dos candidatos reduziu-se apenas um pouco, caindo de 11,8\% para 10,8\%, enquanto entre as mulheres o percentual das que não tinham candidato ou não opinaram caiu de $26,4 \%$ para $14,8 \% .{ }^{77}$

Voltando à pesquisa sobre política econômica, cabe uma observação. Embora um percentual significativo de mulheres tenha optado por não opinar (mais do que o dobro dos homens), uma parcela um pouco superior (28\%) se manifestou pela alternativa de "explorar o petróleo para deixar de importá-lo", resposta que também obteve apoio da maioria dos homens (47\%). Este dado tem importância não só por indicar que movimentos de amplo alcance, como a Campanha do Petróleo (que resultou na criação da Petrobras em outubro de 1953), tinham repercussão junto ao público feminino, como também pelo fato de que, de acordo com a pesquisa de Morente sobre a Federação das Mulheres do Estado de São Paulo, as

73 IBOPE. Série PE (Pesquisas Especiais-Notação PE 014), v. 2, p. 28, 1953 [Arquivo Edgard Leuenroth].

74 IBOPE. Série PE (Pesquisas Especiais-Notação PE 014), v. 3, p. 464, 1954 [Arquivo Edgard Leuernroth].

75 IBOPE. Série PE (Pesquisas Especiais-Notação PE 014), v. 3, p. 474, 1954 [Arquivo Edgard Leuenroth].

76 IBOPE. Série PE (Pesquisas Especiais-Notação PE 014), v. 3, p. 482, 1954 [Arquivo Edgard Leuenroth].

77 IBOPE. Série PE (Pesquisas Especiais-Notação PE 014), v. 3, p. 280, 1954 [Arquivo Edgard Leuenroth]. 
ativistas dessa entidade, assim como das associações a ela filiadas, eram presença constante nas ações em defesa do petróleo, o que permite supor que, em algumas circunstâncias, as posições da Federação das Mulheres tenham influenciado significativamente a formação de opinião do público feminino.

As raras pesquisas com perguntas sobre problemas ligados ao "trabalho reprodutivo" na esfera doméstica mereceram sempre grande atenção das mulheres. Um exemplo é a já mencionada enquete encomendada pela CNC em novembro de 1954. Ao serem questionadas se "de uma maneira geral o(a) sr(a) acha que o comércio brasileiro é ganancioso ou cobra o preço justo pelas mercadorias", apenas $4 \%$ das mulheres não opinaram, contra $7 \%$ dos homens. $86 \%$ julgaram o comércio ganancioso e $10 \%$ opinaram que cobrava o preço justo. ${ }^{78}$

A atenção com a economia doméstica também se manifesta em outra enquete, realizada em fevereiro de 1954, intitulada "Os paulistas e o custo de vida". Ao serem indagados se "de três meses a esta data o(a) senhor(a) acha que o custo de vida aumentou, diminuiu ou continuou como estava?", mais uma vez o percentual das mulheres que não opinaram diferiu muito dos homens: foi zero, enquanto $4 \%$ dos homens não se manifestaram. $95 \%$ das mulheres afirmaram que o custo de vida havia aumentado, $4 \%$ que continuava o mesmo e $1 \%$ que diminuíra. ${ }^{79}$

Esses dados poderiam gerar a falsa conclusão de que na esfera pública simplesmente se reproduziam os mecanismos da divisão sexual do trabalho: os homens dominando os assuntos e os espaços da política e as mulheres circunscritas à economia doméstica. O estudo dos movimentos de defesa do consumidor e de combate à carestia no período revela, ao contrário, que as mulheres, organizadas em sua Federação e nas associações femininas, foram protagonistas de uma decisiva transformação da "esfera pública plebeia", 80 com a politização dos problemas relacionados ao consumo popular e, mais do que isto, com a configuração de uma "economia moral" popular.

Se desagregarmos essa "economia moral" em seus elementos constituintes, veremos que a participação feminina foi fundamental em todos eles. Em primeiro lugar, na atribuição de valores, contrapostos ao lucro e à ganância. A participação feminina conferia "fé pública" à ideia de que a carestia de vida incidia sobre a cesta de gêneros de consumo básico da família proletária, ameaçando sua sobrevivência.

Em segundo lugar, a participação feminina se fazia sentir na crítica aos índices oficiais de inflação, considerados fraudulentos e na elaboração de indicadores "verdadeiros". O índice

78 IBOPE. Série PE (Pesquisas Especiais-Notação PE 014), v. 3, p. 486, 1954 [Arquivo Edgard Leuenroth].

79 IBOPE. Boletim das Classes Dirigentes, n. 164, p. 50, 31 jan. a 6 fev. 1954.

80 Adriano Luiz Duarte argumenta que "[...] quando os movimentos reivindicatórios põem no centro do debate os 'temas privados' - moradia, transporte, escola etc. - eles estão politizando o cotidiano e levando a esfera privada para a rua [...] O que as múltiplas organizações de bairro nos mostram são as trajetórias e os embates para a constituição de uma esfera pública plebeia [...]". Cf.: DUARTE, Adriano Luiz. Cultura popular e cultura política no após-guerra: redemocratização, populismo e desenvolvimentismo no bairro da Mooca, 1942-1973. 2002. Tese (Doutorado em História) - IFCH, Universidade Estadual de Campinas, Campinas, 2002. p. 242. 
de preços ao consumidor mais antigo calculado no Brasil havia sido baseado em cadernetas de compra dos operários da limpeza pública. Uma das críticas a esses números ressaltava a diferença entre os padrões de consumo da classe operária industrial e dos operários da limpeza. Os sindicatos resolveram, então, providenciar outros índices e fizeram uma campanha para que seus associados entregassem suas "cadernetas de empório" nas secretarias das entidades a fim de que os departamentos de contabilidade elaborassem um índice próprio. ${ }^{81}$ Ora, as "cadernetas de empório" eram, certamente na grande maioria das famílias, um acessório organizado e mantido pelas mulheres na administração da economia doméstica. Não custa lembrar que, dessa campanha, amadurecera a ideia de fundar um instituto próprio de pesquisa dos trabalhadores, que veio a ser o Departamento Intersindical de Estatísticas e Estudos Socioeconômicos (Dieese) criado em dezembro de 1955.

Em terceiro lugar, as mulheres participaram das organizações que, na esfera pública, permitiram a formação das coalizões que se contrapuseram tanto ao liberalismo quanto ao desenvolvimentismo, que não se preocupava muito com os efeitos inflacionários de seus projetos. Nas diversas mesas-redondas, convenções populares de combate à carestia e comissões de defesa da economia popular estavam presentes entidades femininas, como a Federação das Mulheres do Estado de São Paulo. Isso vai ocorrer, por exemplo, na mesa-redonda realizada em 13 de setembro de 1955 no Sindicato dos Metalúrgicos de São Paulo, que daria origem à Comissão de Defesa da Economia Popular; 82 na Convenção Popular de Combate à Carestia, realizada em 17 de fevereiro de 1957 no Teatro Colombo, no Brás, que contou com a presença de inúmeras entidades sindicais, femininas e do prefeito Wladimir de Toledo Piza; ${ }^{33}$ na reivindicação, lançada no Congresso da Federação das Mulheres do Estado de São Paulo, em outubro de 1956, da participação das mulheres nos plenários dos órgãos de controle de preços estadual (Coap) e municipal (Comap), bem como na fiscalização dos preços. $^{84}$

As entidades femininas participaram, ainda, da elaboração das teses substantivas da "economia moral" popular. No mesmo Congresso da Federação das Mulheres antes mencionado, segundo a reportagem do Última Hora, "foram discutidos problemas referentes ao transporte das fontes de produção aos centros de consumo, distribuição direta ao consumidor, incentivo à triticultura do Estado, congelamento de taxas escolares, instituição da merenda escolar obrigatória nas escolas públicas [...]". ${ }^{85}$ Diversos "programas mínimos" contra a alta de preços ou "programas de combate à carestia" foram elaborados ao longo dos anos 1950, sempre com participação das entidades femininas, prevendo medidas que iam desde a criação de "órgãos-piloto de abastecimento" para a distribuição de produtos essenciais nos mercados

81 Ata da Assembleia Geral Extraordinária do Sindicato dos Têxteis de São Paulo, 27 jun. 1954, p. 95.

82 MESA-REDONDA promovida por diversos sindicatos. O Metalúrgico, n. 146, p. 3, set. 1955

83 Ata da Assembleia Geral Extraordinária do Sindicato dos Metalúrgicos de São Paulo, 15 fev. 1957, p. 85-verso.

84 REVOLUÇÃO de donas de casa contra a carestia da vida! Última Hora, São Paulo, n. 1390, 15 out. 1956, $1^{\circ}$ caderno, p. 2.

85 Ibidem. 
municipais, mediante contrato entre poder público e comerciantes,$^{86}$ até a reforma agrária e o livre comércio internacional com todos os países do mundo. ${ }^{87}$

Finalmente, as entidades femininas participaram de todas as formas de luta em defesa da "economia moral" popular. Dois exemplos são a "Passeata da Fome", realizada em 28 de novembro de 1958, no centro de São Paulo, reunindo inúmeras entidades da capital e do interior, incluindo o Pacto de Unidade Intersindical (PUI), a Federação das Sociedades Amigos de Bairros, Vilas e Cidades do Estado de São Paulo (Fesab) e a Federação das Mulheres, ${ }^{88} \mathrm{e}$ a greve geral contra a carestia, realizada em 2 de dezembro de 1959.89

O sucesso eleitoral do Movimento da Panela Vazia nas eleições de 1954, elegendo dois deputados federais e três estaduais, embora nenhuma mulher, talvez seja o principal indicador da politização dos problemas associados ao "trabalho reprodutivo" e da mudança da agenda da "esfera pública plebeia", com a inclusão de temas relacionados à reprodução. Essa mudança implicava maior participação feminina nos assuntos públicos, embora não em pé de igualdade e nem tendo uma pauta feminista reconhecida e valorizada.

É de se notar que a emergência dessa agenda nos anos 1950 parece ter sido relativamente abafada nos anos 1960, com a intensificação dos conflitos políticos. A excessiva polarização em torno de temas como movimento dos sargentos pelo direito ao voto, de marinheiros pelo direito à sindicalização, de camponeses pela reforma agrária, de nacionalistas pela estatização das refinarias de petróleo, de revolucionários em defesa de Cuba, de comunistas em defesa da abertura de relações comerciais com todos os países do mundo, prevalecentes nos anos 1960, parece ter encoberto a aliança que vinha se tecendo nos anos 1950 entre assuntos da economia produtiva e da política institucional com assuntos da economia moral popular, com forte influência feminina. $O$ enfraquecimento dessa aliança parece ter significado também um enfraquecimento da politização das questões relacionadas às condições de reprodução da família trabalhadora, que só seria retomada, com grande vigor e amplas repercussões, em meados dos anos 1970.

Recebido em: 08/06/2020

Aprovado em: 25/07/2020

86 Ibidem.

87 DIA 27 de janeiro no Teatro Colombo: provaram os trabalhadores a nossa força sindical. O Metalúrgico, n. 161 , fev. 1957, p. 1.

88 POVO foi às ruas reclamar contra carestia e fome! Última Hora, n. 2037, São Paulo, p. 1, 29 nov. 1958.

89 MESMO reprimida a greve alcançou o objetivo. O Metalúrgico, n. 187, São Paulo, p. 1, dez. 1959. 